\title{
Aquipuribacter hungaricus gen. nov., sp. nov., an actinobacterium isolated from the ultrapure water system of a power plant
}

\author{
Correspondence \\ Peter Schumann \\ psc@dsmz.de
}

\author{
E. M. Tóth, ${ }^{1}$ Zs. Kéki, ${ }^{1}$ V. Bohus, ${ }^{1}$ A. K. Borsodi, ${ }^{1}$ K. Márialigeti ${ }^{1}$ \\ and P. Schumann ${ }^{2}$ \\ ${ }^{1}$ Eötvös Loránd University, Faculty of Science, Department of Microbiology, \\ Pázmány Péter sétány 1/c, H-1117 Budapest, Hungary \\ ${ }^{2}$ Leibniz Institute DSMZ - German Collection of Microorganisms and Cell Cultures, \\ Inhoffenstrasse 7B, D-38124 Braunschweig, Germany
}

\begin{abstract}
A Gram-positive actinobacterium, strain $\mathrm{IV}-75^{\top}$, was isolated by using $\mathrm{R} 2 \mathrm{~A}$ agar from the ultrapure water system of a power plant in Hungary. The strain exhibited a rod-coccus cell cycle, and was strictly aerobic, non-motile, catalase-positive and oxidase-negative. 16S rRNA gene sequence analysis revealed that strain IV- $75^{\top}$ belonged to the suborder Micrococcineae and clustered with members of the family Intrasporangiaceae. Its closest phylogenetic neighbour was Arsenicicoccus bolidensis CCUG $47306^{\top}$ (94.3\% 16S rRNA gene sequence similarity). The peptidoglycan of strain IV- $75^{\top}$ contained meso-diaminopimelic acid and $\mathrm{MK}-10\left(\mathrm{H}_{4}\right)$ was the major menaquinone. The polar lipid pattern contained phosphatidylglycerol, two unidentified phospholipids, one glycolipid and several other lipid components. The major fatty acids were anteiso- $\mathrm{C}_{15: 0}, \mathrm{C}_{18: 1} \omega 9 \mathrm{c}$ and $\mathrm{C}_{16: 0}$. Based on the moderate levels of $16 \mathrm{~S}$ rRNA gene sequence similarity to all members of the family Intrasporangiaceae and the unique combination of chemotaxonomic characteristics, strain $I V-75^{\top}$ is considered to represent a novel species of a new genus, for which the name Aquipuribacter hungaricus gen. nov., sp. nov. is proposed. The type strain of Aquipuribacter hungaricus is IV $-75^{\top}$ (=DSM $21674^{\top}=$ NCAIM B $02333^{\top}$ ).
\end{abstract}

Many industrial applications use ultrapure water (UPW) as a basic material. Despite the fact that UPW generally contains very low levels of organic (total organic carbon $<3 \mathrm{mg}$ ) and inorganic (conductivity $<1 \mu \mathrm{S} \mathrm{m}^{-1}$ ) material, it is well known that oligotrophic bacteria can grow and proliferate in such nutrient-deficient environments (Patterson et al., 1991; Poindexter, 1981; Soini et al., 2002). Planktonic microorganisms can be dispersed within the water body but many also attach to surfaces and form biofilms. Micro-organisms that colonize industrial cooling water systems can affect the efficiency of various operation units and their by-products may cause or speed up corrosion (Costerton et al., 1987).

In 2007, the water purification system of a Hungarian power plant was studied by using cultivation and cultivation-independent methods (Bohus et al., 2010). Among the isolated bacteria, one strain, designated IV $-75^{\mathrm{T}}$, was found to be only distantly related to any recognized taxon based on its

Abbreviation: UPW, ultrapure water.

The GenBank/EMBL/DDBJ accession number for the 16S rRNA gene sequence of strain IV- $75^{\top}$ is $\mathrm{FM} 179321$.

Two supplementary figures are available with the online version of this paper.
16S rRNA gene sequence. The aim of the present study was to describe strain IV $-75^{\mathrm{T}}$ and determine its taxonomic position using a polyphasic approach.

Sampling was carried out in a power plant close to the town of Paks. Water for the plant is taken from the River Danube and is treated in a purification system consisting of mechanical filtration, lime softening, and scavenger, cationic, anionic and mixed-bed ion exchange units; the resulting UPW is stored in a tank before it is loaded into the circulation system (Bohus et al., 2010). UPW for isolation of bacteria was sampled with extreme care under aseptic conditions, collected in sterilized screw-capped flasks and transferred to the laboratory at $4{ }^{\circ} \mathrm{C}$. The oligotrophic medium R2A agar (Reasoner \& Geldreich, 1985) was used for cultivation of bacteria by direct plating. All plates were incubated at $28{ }^{\circ} \mathrm{C}$ for 5-10 days. Later, bacterial colonies were purified and the strains were maintained on R2A agar slants.

Colony morphology was studied on R2A agar medium by direct and stereomicroscopic observations of single colonies. Cell size, shape, arrangement and motility were studied by using native preparations and by Gram staining according to Claus (1992). Endospore and acid-fast staining tests were carried out according to the method of Murray et al. (1994). 
Scanning electron microscopic investigations were based on techniques described by Makk \& Ács (1996).

Growth under anaerobic conditions was examined using slant agar cultures on R2A agar medium incubated for 1 week in an anaerobic chamber (Forma Scientific) at $28{ }^{\circ} \mathrm{C}$. Oxidase activity was tested by the method of Tarrand \& Gröschel (1982). Catalase production and the VogesProskauer reaction were demonstrated by using the methods of Cowan \& Steel (1974). Acid production from glucose was studied by the OF test according to Hugh \& Leifson (1953). Growth at 4, 20, 28, 37, 45 and $60{ }^{\circ} \mathrm{C}$ was determined on R2A agar slants. $\mathrm{NaCl}$ tolerance $(0,2.5,5,10 \%, \mathrm{w} / \mathrm{v})$ and $\mathrm{pH}$ tolerance (3-11, steps of $1.0 \mathrm{pH}$ unit) were checked in R2A broth. Urease activity, nitrate reduction, starch hydrolysis, indole production from tryptophan, caseinase, gelatinase, phosphatase activity, hydrolysis of Tween 80 and $\mathrm{H}_{2} \mathrm{~S}$ production from cysteine were studied according to Smibert \& Krieg (1994). Acid production from different carbon sources as sole source of carbon and enzyme activities were tested by using the API $50 \mathrm{CH}$ and API ZYM systems (bioMérieux) according to the manufacturer's instructions.

The cell-wall diamino acid of strain IV- $75^{\mathrm{T}}$ was determined from whole-cell hydrolysates as described by Hasegawa et al. (1983). Isoprenoid quinones were extracted from cells cultivated in liquid Rich medium (Yamada \& Komagata, 1972) according to the method of Collins et al. (1977) and were analysed by HPLC (Shimadzu LC 20A) and electronimpact MS [Singlequad 320 instrument equipped with a direct insertion device; Varian (Groth et al., 1997)]. Cellular fatty acids were extracted from cells cultivated on R2A agar at $28{ }^{\circ} \mathrm{C}$. Strain IV $-75^{\mathrm{T}}$ and the three strains of recognized Arsenicicoccus species included in the fatty acid analyses showed similar growth behaviour and sufficient cells of comparable physiological age could be harvested from the third streak quadrant of the plates after cultivation under the conditions used. Fatty acid methyl esters were obtained following the method of Stead et al. (1992) and were analysed by GC via the Microbial Identification System (MIDI, Sherlock Version 6.1; TSBA40 database; Agilent Technologies model $6890 \mathrm{~N}$ GC). Summed feature components were identified thereafter by GC/MS by using a Singlequad 320 instrument (Varian). Polar lipids were determined according to the method described by Minnikin et al. (1979) and were separated by two-dimensional TLC. To identify spots, ninhydrin reagent, Zinzadze reagent and molybdophosphoric acid were used (Embley \& Wait, 1994). Genomic DNA for analysis of the $\mathrm{G}+\mathrm{C}$ content was isolated after disruption of bacterial cells by using a French press (Thermo Spectronic). After purification on hydroxyapatite according to the procedure of Cashion et al. (1977), the DNA was degraded to nucleosides by using P1 nuclease and bovine intestinal mucosa alkaline phosphatase as described by Mesbah et al. (1989). The nucleosides were separated by reversed-phase HPLC (Shimadzu LC 20A) according to the method described by Tamaoka \& Komagata (1984). The G+C content of the DNA was calculated from the ratio of deoxyguanosine to thymidine.
DNA extraction from strain $\mathrm{IV}-75^{\mathrm{T}}$ and PCR-mediated amplification of the $16 \mathrm{~S}$ rRNA gene were carried out by using the method of Rainey et al. (1996). The PCR product was purified with a Prep-A-Gene kit (Bio-Rad). Cycle sequencing was performed by using a Big Dye Terminator Cycle Sequencing kit (Applied Biosystems) according to the manufacturer's protocol. The PCR product was purified with the PCR-M Clean Up System (Viogene). Sequence analysis was performed by using an Applied Biosystems model 310 Genetic Analyzer.

The search for phylogenetically related type strains was initially carried out via the BLAST (Altschul et al., 1997) and FASTA (Pearson \& Lipman, 1988) programs as well as by using the EzTaxon Server (version 2.1; Chun et al., 2007).

Because preliminary searches revealed members of the suborder Micrococcineae to be the closest relatives of strain $\mathrm{IV}-75^{\mathrm{T}}$, the sequences of all type strains of type species of genera classified in this suborder (Schumann et al., 2009; Euzéby, 1997; http://www.bacterio.cict.fr/) were chosen for comparison. The $16 \mathrm{~S}$ rRNA gene sequence of strain IV $-75^{\mathrm{T}}$ was manually aligned with the program BioEdit (Hall, 1999) against sequences available from EMBL (http://www. ncbi.nlm.nih.gov/). The alignment was used to calculate

Table 1. Patterns of $16 \mathrm{~S}$ rRNA gene signature nucleotides of strain IV- $75^{\top}$ and of those defining the families Intrasporangiaceae, Dermatophilaceae and Dermacoccaceae

Taxa: 1, strain IV $-75^{\mathrm{T}} ; 2$, Intrasporangiaceae; 3, Dermatophilaceae; 4, Dermacoccaceae. Nucleotides in lower-case letters are present in some but not all strains; Y, C or U; K, G or U; signature nucleotides different from those of strain IV $-75^{\mathrm{T}}$ are indicated in bold.

\begin{tabular}{|lcccc|}
\hline Position(s) & $\mathbf{1}$ & $\mathbf{2}^{\star}$ & $\mathbf{3}^{\star}$ & $\mathbf{4}^{\star}$ \\
\hline 120 & A & A & A & A \\
$131: 231$ & A-G & A-G & Y-K & A-G \\
196 & U & G & A & C \\
$342: 347$ & C-G & C-G & C-G & C-G \\
$444: 490$ & U-A & a-u & A-U & A-U \\
$580: 761$ & C-G & U-A & U-A & U-A \\
$602: 636$ & C-G & C-G & C-G & C-G \\
$670: 736$ & A-U & A-U & A-U & A-U \\
$822: 878$ & G-C & G-C & G-C & G-C \\
$823: 877$ & G-C & G-C & G-C & G-C \\
$826: 874$ & C-G & C-G & C-G & C-G \\
827 & U & U & U & U \\
843 & C & U & U & c \\
$950: 1231$ & U-A & U-A & U-A & U-A \\
$1047: 1210$ & G-C & G-C & G-C & G-C \\
1109 & C & C & C & C \\
1145 & G & G & G & G \\
$1309: 1328$ & G-C & G-C & G-C & G-C \\
1361 & G & C & G & G \\
1383 & C & C & C & C \\
& & & & \\
\hline
\end{tabular}

${ }^{\star}$ Data from Zhi et al. (2009). 
a distance matrix based on the Kimura two-parameter correction (Kimura, 1980) and to construct a phylogenetic tree with the neighbour-joining method (Saitou \& Nei, 1987) within the CLUSTAL X software package (Thompson et al., 1997). Bootstrap analysis was based on 1000 resamplings (Felsenstein, 1985). Within the phylogenetic tree based on $16 \mathrm{~S}$ rRNA gene sequences of the type strains of type species of the suborder Micrococcineae, strain IV- $75^{\mathrm{T}}$ fell within a clade comprising members of the families Intrasporangiaceae, Dermacoccaceae and Dermatophilaceae (see Supplementary Fig. S1 in IJSEM Online). The clustering of strain IV $-75^{\mathrm{T}}$ within the subcluster of Arsenicicoccus bolidensis and Ornithinimicrobium humiphilum was supported by a moderate bootstrap value of $51 \%$. The signature nucleotides of the 16S rRNA gene sequence of strain $\mathrm{IV}-75^{\mathrm{T}}$ were determined and compared with those that define the families Intrasporangiaceae, Dermacoccaceae and Dermatophilaceae (Zhi et al., 2009). Because the signature nucleotides of strain IV $-75^{\mathrm{T}}$ differed in three to five positions from those of these three families (Table 1), unambiguous affiliation at the level of families on the basis of signature nucleotides was not possible. The clustering of strain IV- $75^{\mathrm{T}}$ with the type strains of type species of the genera Arsenicicoccus and
Ornithinimicrobium (both belonging to the family Intrasporangiaceae) in a phylogenetic tree representing the suborder Micrococcineae (Supplementary Fig. S1) supports the view that strain IV $-75^{\mathrm{T}}$ should be considered a member of the family Intrasporangiaceae. A phylogenetic tree was constructed by the methods described above based on $16 \mathrm{~S}$ rRNA gene sequences of representatives of all genera classified within the family Intrasporangiaceae at the time of writing (Fig. 1; http://www.bacterio.cict.fr/). Strain IV $-75^{\mathrm{T}}$ fell within a subcluster encompassing members of the genera Arsenicicoccus, Ornithinimicrobium and Serinicoccus. The clustering of strain IV $-75^{\mathrm{T}}$ with these three genera was confirmed by a maximum-likelihood analysis (Felsenstein, 1985) performed by using the program BioEdit (Hall, 1999; data not shown). Strain IV $-75^{\mathrm{T}}$ showed the following levels of 16S rRNA gene sequence similarity to those of its closest relatives calculated by using the EzTaxon server (Chun et al., 2007; http://www.eztaxon.org): Arsenicicoccus bolidensis CCUG 47306 ${ }^{\mathrm{T}}, 94.3 \%$; Arsenicicoccus piscis Kis4-19 ${ }^{\mathrm{T}}$, 93.6\%; Ornithinimicrobium kibberense $\mathrm{K} 22-20^{\mathrm{T}}$, $94.0 \%$; Ornithinimicrobium humiphilum DSM $12362^{\mathrm{T}}$, 93.2\%; Ornithinimicrobium pekingense $\mathrm{LW6}^{\mathrm{T}}, \quad 92.7 \%$; Serinicoccus profundi $0714 \mathrm{~S} 6-1^{\mathrm{T}}$, $92.1 \%$; Serinicoccus marinus

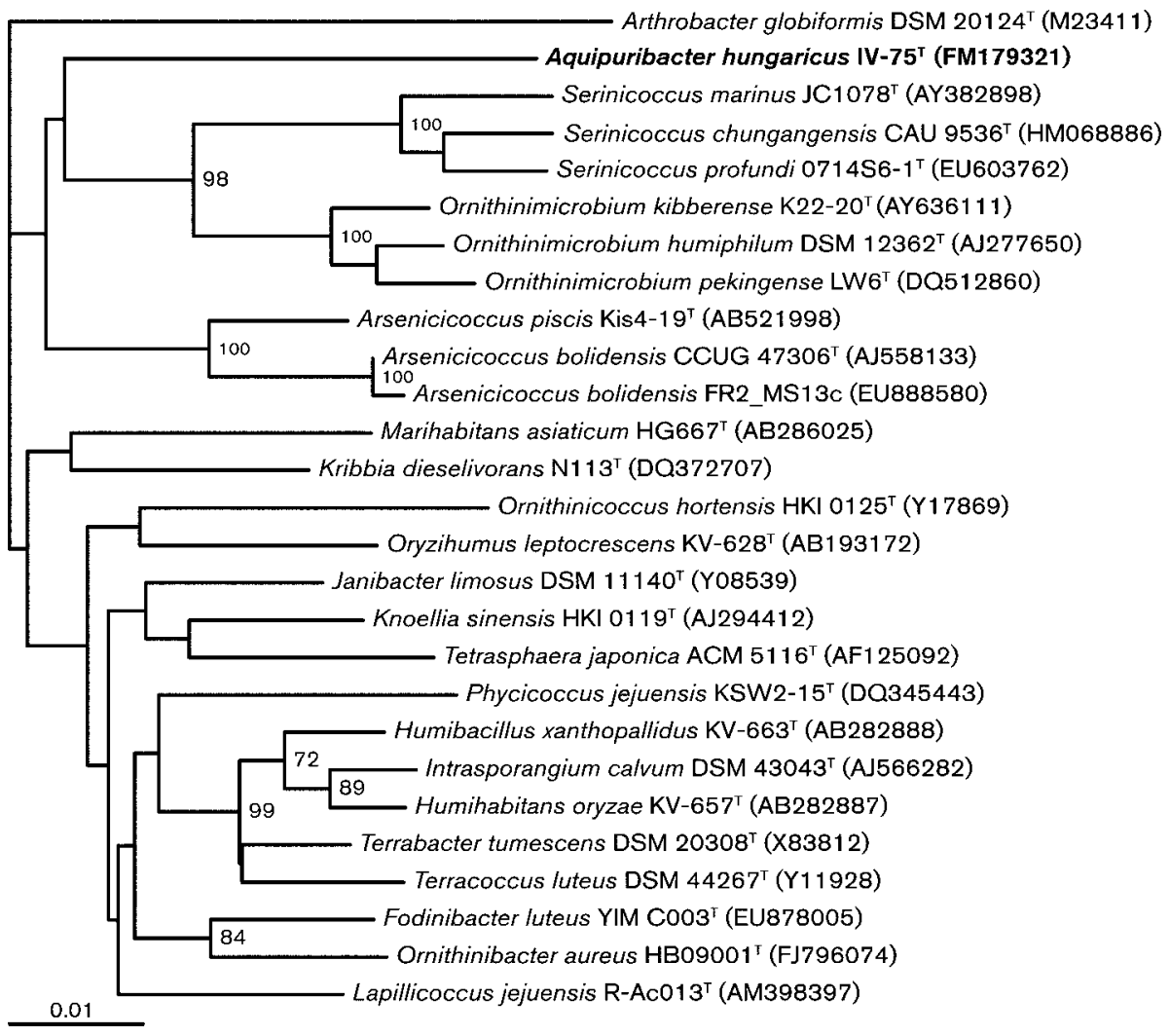

Fig. 1. Neighbour-joining tree constructed from $16 \mathrm{~S}$ rRNA gene sequences of strain $I V-75^{\top}$ and representatives of genera classified in the family Intrasporangiaceae. Arthrobacter globiformis DSM $20124^{\top}$ was used as outgroup. Bootstrap values (expressed as percentages of 1000 replications) are given at branch points; only values $>70 \%$ are shown. Bar, 0.01 substitutions per nucleotide position. 
Table 2. Differential characteristics of strain $\mathrm{IV}-75^{\top}$ and related genera

Taxa: 1, strain IV $-75^{\mathrm{T}}$ (data from this study); 2, Arsenicicoccus [data from Collins et al. (2004) and Hamada et al. (2009)]; 3, Ornithinimicrobium [data from Groth et al. (2001), Mayilraj et al. (2006) and Liu et al. (2008)]; 4, Serinicoccus [data from Yi et al. (2004), Traiwan et al. (2011) and Xiao et al. (2011)]. ND, No data available. Data in square brackets were reported for only a few species.

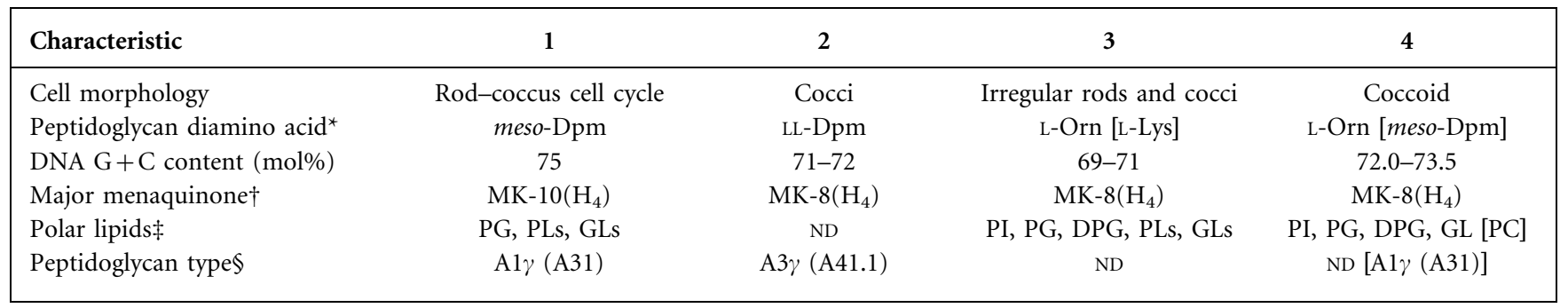

${ }^{\star}$ Dpm, 2,6-Diaminopimelic acid; Lys, lysine; Orn, ornithine.

†Example for isoprenoid quinones: MK-8 $\left(\mathrm{H}_{4}\right)$, partially saturated menaquinone with two of eight isoprene units hydrogenated.

末DPG, Diphosphatidylglycerol; GL(s), unidentified glycolipid(s); PC, phosphatidylcholine; PG, phosphatidylglycerol; PI, phosphatidylinositol; $\mathrm{PL}(\mathrm{s})$, unidentified phospholipid(s).

\$Data given in parentheses are according to Schleifer \& Kandler (1972) and DSMZ (http://www.dsmz.de/).

JC1078 ${ }^{\mathrm{T}}, 91.9 \%$; and Serinicoccus chungangensis CAU $9536^{\mathrm{T}}$, $91.9 \%$.

Differential characteristics of strain IV $-75^{\mathrm{T}}$ and related genera are shown in Table 2. Because strain IV $-75^{\mathrm{T}}$ showed highest $16 \mathrm{~S}$ rRNA gene sequence similarity to members of the genus Arsenicicoccus, its physiological and biochemical characteristics as well as itsfatty acid profile were compared with those of strains of this genus (Tables 3 and 4) side by side. To represent the phenotypic diversity of the genus Arsenicicoccus, Arsenicicoccus bolidensis DSM $15745^{\mathrm{T}}$, Arsenicicoccus piscis DSM $22760^{\mathrm{T}}$ and Arsenicicoccus bolidensis DSM 30750 (isolate FR2_MS13 from a spacecraft-associated clean room, Stieglmeier et al., 2009; sharing 94.1\% 16S rRNA gene sequence similarity with strain $\mathrm{IV}-75^{\mathrm{T}}$ ) were included in this study.

Strain IV $-75^{\mathrm{T}}$ differed from all representatives of the genus Arsenicicoccus based on its morphological cell cycle (Fig. 2), in being negative in the nitrate reduction test, in its ability to use L-arabinose and potassium-5-ketogluconate as sole source of carbon, and in its inability to utilize a series of Disomer sugars (Table 3 ). In contrast to members of the genus Arsenicicoccus, strain IV $-75^{\mathrm{T}}$ showed valine arylamidase and $\mathrm{N}$-acetylglucosaminidase activity but no naphthol-AS-BIphosphohydrolase activity (Table 3 ).

The cellular fatty acid profile of strain $\mathrm{IV}-75^{\mathrm{T}}$ contained anteiso- $C_{15: 0}, C_{18: 1} \omega 9 c$ and $C_{16: 0}$ as major components and differed by a lower content of iso- $\mathrm{C}_{15: 0}$ and higher amounts of anteiso- $\mathrm{C}_{15: 0}$ and $\mathrm{C}_{18: 1} \omega 9 c$ compared with all three reference Arsenicicoccus strains (Table 4). Strain IV$75^{\mathrm{T}}$ could be distinguished from Arsenicicoccus bolidensis by a lower $\mathrm{C}_{16: 1} \omega 7 c$ content and from Arsenicicoccus piscis by a much higher $\mathrm{C}_{18: 1} \omega 9 c$ content.

Strain IV- $75^{\mathrm{T}}$ contained MK-10 $\left(\mathrm{H}_{4}\right)$ as the major menaquinone, in contrast to members of the genera Arsenicicoccus, Ornithinimicrobium and Serinicoccus, which all contain menaquinone $\mathrm{MK}-8\left(\mathrm{H}_{4}\right)$. The diamino acid meso-diaminopimelic acid found in strain IV $-75^{\mathrm{T}}$ was detected only in one species of the genus Serinicoccus, S. chungangensis (Traiwan et al., 2011), whereas other members of the genus Serinicoccus contain ornithine. Species of the genus Arsenicicoccus display LLdiaminopimelic acid and species of the genus Ornithinimicrobium contain ornithine ( $O$. pekingense additionally contains lysine; Liu et al., 2008) (Table 2). The polar lipid profile of strain IV $-75^{\mathrm{T}}$ contained mainly unidentified components (see Supplementary Fig. S2 available in IJSEM Online). Three phospholipids (including phosphatidylglycerol), one glycolipid and several other lipid components but no aminolipids were detected.

Strain IV $-75^{\mathrm{T}}$ fell within the clade encompassing the suborder Micrococcineae but showed less than $94.5 \% 16 \mathrm{~S}$ rRNA gene sequence similarity to its members. Its major menaquinone, MK-10 $\left(\mathrm{H}_{4}\right)$, has been found so far only in the distantly related genus Actinotalea (Schumann et al., 2009); strain IV $-75^{\mathrm{T}}$ shared $92.6 \% 16 \mathrm{~S}$ rRNA gene sequence similarity with the type strain of Actinotalea fermentans, the single recognized species of the genus. We suggest classifying strain IV $-75^{\mathrm{T}}$ tentatively within the family Intrasporangiaceae despite differences in 16S rRNA gene signature nucleotides because of its phylogenetic association with the genera Arsenicicoccus, Ornithinimicrobium and Serinicoccus. Based on moderate 16S rRNA gene sequence similarity to members of these genera and its unique combination of chemotaxonomic characteristics and differences in phenotypic characteristics from both recognized species of the genus Arsenicicoccus (Table 3), we suggest that strain IV $-75^{\mathrm{T}}$ represents a novel species of a new genus, for which the name Aquipuribacter hungaricus gen. nov., sp. nov. is proposed.

\section{Description of Aquipuribacter gen. nov.}

Aquipuribacter (A.qui.pu.ri.bac'ter. L. n. aqua water; L. adj. purus clean, pure; N.L. masc. n. bacter a rod; N.L. masc. n. Aquipuribacter a rod isolated from pure water). 
Table 3. Differential physiological and biochemical characteristics of strain IV $-75^{\top}$ and strains of recognized Arsenicicoccus species

Strains: 1, IV-75 ${ }^{\mathrm{T}}$; 2, Arsenicicoccus bolidensis DSM $15745^{\mathrm{T}}$; 3, Arsenicicoccus bolidensis DSM 30750; 4, Arsenicicoccus piscis DSM $22760^{\mathrm{T}}$. All results are from this study. All strains were positive for catalase, $\alpha$-chymotrypsin, acid phosphatase, $\beta$-galactosidase and $\alpha$ glucosidase activities and aesculin hydrolysis. All strains were negative for oxidase, urease, casease, gelatinase, phosphatase, lipase (C14), $\beta$ glucuronidase, $\alpha$-mannosidase and $\alpha$-fucosidase activities and utilization of glycerol, erythritol, D-arabinose, D-ribose, L-xylose, D-adonitol, methyl $\beta$-xylopyranoside, D-mannose, L-sorbose, L-rhamnose, dulcitol, inositol, D-sorbitol, methyl $\alpha$-D-mannopyranoside, methyl $\alpha$-D-glucopyranoside, amygdalin, inulin, melezitose, starch, xylitol, turanose, Dlyxose, D-tagatose, D-fucose, L-fucose, D-arabitol, L-arabitol, potassium gluconate and potassium 2-ketogluconate. All strains were negative for $\mathrm{H}_{2} \mathrm{~S}$ and indole production and for the Voges-Proskauer test. None of the strains was able to grow at $\mathrm{pH} 3,4,10$ or 11 or with $10 \% \mathrm{NaCl}$.

\begin{tabular}{|c|c|c|c|c|}
\hline Characteristic & 1 & 2 & 3 & 4 \\
\hline Salinity range for growth $(\% \mathrm{NaCl})$ & $0-2.5$ & $0-5$ & $0-5$ & $0-2.5$ \\
\hline $\mathrm{pH}$ range for growth & $6-9$ & $5-9$ & $5-9$ & $6-8$ \\
\hline Nitrate reduction to nitrite & - & + & + & + \\
\hline \multicolumn{5}{|l|}{ Hydrolysis of: } \\
\hline Starch & + & + & + & - \\
\hline Tween 80 & - & + & + & - \\
\hline \multicolumn{5}{|l|}{ Acid production from: } \\
\hline L-Arabinose & + & - & - & - \\
\hline D-Xylose & - & + & + & - \\
\hline D-Fructose & - & + & + & + \\
\hline D-Galactose & - & + & + & - \\
\hline D-Glucose & - & + & + & + \\
\hline D-Mannitol & - & + & + & - \\
\hline Arbutin & - & + & + & - \\
\hline $\mathrm{N}$-Acetylglucosamine & - & + & - & - \\
\hline Salicin & - & + & + & - \\
\hline Cellobiose & - & + & + & - \\
\hline Maltose & - & + & + & + \\
\hline Lactose & - & + & + & - \\
\hline Melibiose & - & + & + & - \\
\hline Sucrose & - & + & + & + \\
\hline Trehalose & - & + & + & - \\
\hline Raffinose & - & + & + & + \\
\hline D-Xylose & - & + & + & - \\
\hline Gentiobiose & - & + & + & - \\
\hline Glycogen & - & + & - & + \\
\hline Potassium 5-ketogluconate & + & - & - & - \\
\hline Alkaline phosphatase & + & + & + & - \\
\hline Esterase (C4) & + & + & + & - \\
\hline Esterase lipase (C8) & + & + & + & - \\
\hline Leucine arylamidase & + & + & + & - \\
\hline Valine arylamidase & + & - & - & - \\
\hline Cystine arylamidase & + & - & - & - \\
\hline Trypsin & - & - & - & + \\
\hline Naphthol-AS-BI-phosphohydrolase & - & + & + & + \\
\hline$\alpha$-Galactosidase & + & + & - & - \\
\hline$\beta$-Glucosidase & + & + & - & + \\
\hline$N$-Acetyl- $\beta$-glucosaminidase & + & - & - & - \\
\hline
\end{tabular}

Table 4. Cellular fatty acid composition of strain $\mathrm{IV}-75^{\top}$ and strains of recognized Arsenicicoccus species

Strains: 1, IV- $-75^{\mathrm{T}} ; 2$, Arsenicicoccus bolidensis DSM $15745^{\mathrm{T}} ; 3$, Arsenicicoccus bolidensis DSM 30750; 4, Arsenicicoccus piscis DSM $22760^{\mathrm{T}}$. All strains were cultivated on R2A agar at $28{ }^{\circ} \mathrm{C}$ for $72 \mathrm{~h}$ and fatty acids were analysed in parallel in the present study. - , Not detected.

\begin{tabular}{|c|c|c|c|c|}
\hline Fatty acid & 1 & 2 & 3 & 4 \\
\hline \multicolumn{5}{|c|}{ Saturated straight-chain } \\
\hline $\mathrm{C}_{13: 0}$ & - & 0.1 & - & - \\
\hline $\mathrm{C}_{14: 0}$ & 1.3 & 2.3 & 1.6 & - \\
\hline $\mathrm{C}_{15: 0}$ & 0.7 & 2.2 & 1.3 & 0.8 \\
\hline $\mathrm{C}_{16: 0}$ & 9.2 & 11.1 & 5.3 & 1.6 \\
\hline $\mathrm{C}_{17: 0}$ & 3.9 & 4.6 & 2.2 & 4.2 \\
\hline $\mathrm{C}_{18: 0}$ & 7.3 & 4.2 & 1.3 & 1.9 \\
\hline $\mathrm{C}_{19: 0}$ & - & 0.1 & - & - \\
\hline $\mathrm{C}_{16: 0} \mathrm{~N}$ alcohol & 1.2 & - & - & - \\
\hline \multicolumn{5}{|c|}{ Unsaturated straight-chain } \\
\hline $\mathrm{C}_{15: 1} \omega 6 c$ & - & 0.4 & 0.5 & - \\
\hline $\mathrm{C}_{16: 1} \omega 7 c^{\star}$ & 1.4 & 12.9 & 14.1 & 1.5 \\
\hline $\mathrm{C}_{17: 1} \omega 8 c$ & 0.8 & 4.2 & 5.7 & 4.3 \\
\hline $\mathrm{C}_{18: 1} \omega 9 c$ & 17.5 & 11.2 & 12.8 & 1.4 \\
\hline $\mathrm{C}_{18: 3} \omega 6 c(6,9,12)$ & 7.8 & - & - & - \\
\hline Summed feature $6 \dagger$ & - & 0.2 & 0.3 & - \\
\hline \multicolumn{5}{|c|}{ Saturated branched-chain } \\
\hline iso- $\mathrm{C}_{13: 0}$ & 0.3 & 2.9 & 0.9 & 1.1 \\
\hline iso- $\mathrm{C}_{14: 0}$ & 2.2 & 13.7 & 10.1 & 5.5 \\
\hline iso- $\mathrm{C}_{15: 0}$ & 5.3 & 14.8 & 21.6 & 37.4 \\
\hline iso- $\mathrm{C}_{16: 0}$ & 3.8 & 4.1 & 8.7 & 11.8 \\
\hline iso- $\mathrm{C}_{17: 0}$ & 3.0 & 0.6 & 1.3 & 2.5 \\
\hline anteiso- $\mathrm{C}_{13: 0}$ & - & 1.2 & 0.3 & - \\
\hline anteiso- $\mathrm{C}_{15: 0}$ & 29.8 & 7.3 & 6.3 & 10.2 \\
\hline anteiso- $\mathrm{C}_{17: 0}$ & 4.6 & 1.2 & 2.1 & 5.9 \\
\hline 10-Methyl- $\mathrm{C}_{17: 0}$ & - & - & 0.4 & 1.0 \\
\hline 10-Methyl- $\mathrm{C}_{18: 0}$ & - & - & 0.2 & - \\
\hline \multicolumn{5}{|c|}{ Unsaturated branched-chain } \\
\hline iso- $\mathrm{C}_{15: 1} \omega 9 c$ & - & - & 0.1 & 1.4 \\
\hline iso- $\mathrm{C}_{16: 1}$ & - & - & 0.6 & 2.2 \\
\hline iso- $\mathrm{C}_{17: 1} \omega 9 c$ & - & 0.2 & 1.3 & 2.5 \\
\hline anteiso- $\mathrm{C}_{17: 1} \omega 9 c$ & - & - & 0.8 & 2.8 \\
\hline
\end{tabular}

${ }^{\star}$ Identified as part of summed feature $3\left(\mathrm{C}_{16: 1} \omega 7 c\right.$ and/or iso- $\mathrm{C}_{15}$ 2-OH) but identified as $\mathrm{C}_{16: 1} \omega 7 c$ by GC/MS.

$\dagger$ Summed feature 6 comprised $\mathrm{C}_{19: 1} \omega 11 c$ and/or $\mathrm{C}_{19: 1} \omega 9 c$.

Cells exhibit a rod-coccus cycle, are aerobic and nonendospore-forming, and stain Gram-positive. The peptidoglycan type is $\mathrm{A} 1 \gamma$ based on directly cross-linked meso-diaminopimelic acid. The predominant menaquinone is $\mathrm{MK}-10\left(\mathrm{H}_{4}\right)$ and the major polar lipids are phosphatidylglycerol, two unidentified phospholipids and one glycolipid. The major cellular fatty acids are anteiso- $\mathrm{C}_{15: 0}, \mathrm{C}_{18: 1} \omega 9 c$ and $\mathrm{C}_{16: 0}$. The $\mathrm{G}+\mathrm{C}$ value of the genomic DNA is approximately 75 mol\%. Phylogenetically, the genus belongs to the family Intrasporangiaceae, suborder Micrococcineae, within the order Actinomycetales. The type species is Aquipuribacter hungaricus. 

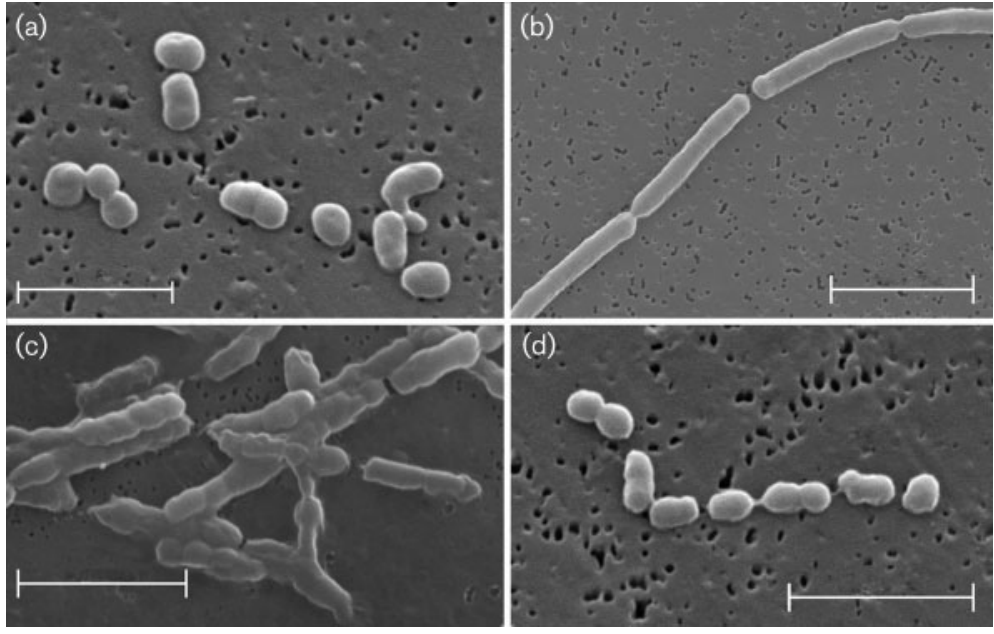

Fig. 2. Scanning electron micrographs demonstrating the typical cell cycle of strain IV- $75^{\top}$ grown in R2A broth. In the first $44 \mathrm{~h}$ of growth, cells occur mainly as single cocci (a). After $44 \mathrm{~h}$, cells start to elongate to become regular rods, reaching a maximum length after 76$84 \mathrm{~h}$ cultivation (b). After approximately $90 \mathrm{~h}$, the rods constrict to give 4-5 coccoid bodies per cell. Some of the cells show a tendency to branch (c). After $96 \mathrm{~h}$ of cultivation, cells revert to a coccoid morphology (d). Bars, $5 \mu \mathrm{m}$.

\section{Description of Aquipuribacter hungaricus sp. nov.}

Aquipuribacter hungaricus (hun.ga' ri.cus. M.L. masc. adj. hungaricus of or belonging to Hungary, where the type strain was isolated).

Displays the following characteristics in addition to those given for the genus. Rods are $0.9-1.1 \mu \mathrm{m}$ by $3.8-6.2 \mu \mathrm{m}$; cocci are $0.9-1.4 \mu \mathrm{m}$ in diameter. Cells are non-motile. Colonies are pale orange, smooth, convex and circular on R2A agar medium after 7 days of incubation. Catalasepositive and oxidase-negative. Growth occurs with up to $2.5 \% \mathrm{NaCl}$. The temperature range for growth on $\mathrm{R} 2 \mathrm{~A}$ agar is $20-37{ }^{\circ} \mathrm{C}$ with an optimal temperature between 20 and $28{ }^{\circ} \mathrm{C}$. The $\mathrm{pH}$ optimum is $7-8$. Does not reduce nitrate to nitrite. L-Arabinose and potassium-5-ketogluconate are utilized but the following carbon sources are not: D-xylose, D-fructose, D-galactose, D-glucose, D-mannitol, arbutin, cellobiose, maltose, lactose, melibiose, sucrose, trehalose, raffinose, D-xylose, gentiobiose, $\mathrm{N}$-acetylglucosamine and salicin. Aesculin is hydrolysed. $\mathrm{H}_{2} \mathrm{~S}$ and indole are not produced. Alkaline phosphatase, acid phosphatase, esterase (C4), esterase lipase (C8), leucine arylamidase, $\alpha$-chymotrypsin, valine arylamidase, $N$-acetylglucosaminidase, $\alpha$-galactosidase, $\beta$-galactosidase, $\alpha$-glucosidase and $\beta$-glucosidase are present but naphthol-AS-BI-phosphohydrolase and trypsin are absent. The peptidoglycan contains meso-diaminopimelic acid and the major menaquinone is $\mathrm{MK}-10\left(\mathrm{H}_{4}\right)$. The major cellular fatty acids are anteiso- $\mathrm{C}_{15: 0}, \mathrm{C}_{18: 1} \omega 9 c$ and $\mathrm{C}_{16: 0}$.

The type strain, IV $-75^{\mathrm{T}} \quad\left(=\mathrm{DSM} \quad 21674^{\mathrm{T}}=\right.$ NCAIM B $02333^{\mathrm{T}}$ ), was isolated from UPW of a Hungarian power plant. The DNA $\mathrm{G}+\mathrm{C}$ content of the type strain is $75.0 \mathrm{~mol} \%$ (HPLC).

\section{Acknowledgements}

We thank Rüdiger Pukall (curator at DSMZ) for providing and culturing the Arsenicicoccus reference strains as well as Anika Wasner and Gabriele Pötter (both DSMZ) for excellent technical assistance.
We gratefully acknowledge the help of Judit Makk (Eötvös Loránd University) who produced the electron micrographs.

\section{References}

Altschul, S. F., Madden, T. L., Schäffer, A. A., Zhang, J., Zhang, Z., Miller, W. \& Lipman, D. J. (1997). Gapped BLAST and PSI-BLAST: a new generation of protein database search programs. Nucleic Acids Res 25, 3389-3402.

Bohus, V., Tóth, E. M., Székely, A. J., Makk, J., Baranyi, K., Patek, G., Schunk, J. \& Márialigeti, K. (2010). Microbiological investigation of an industrial ultra pure supply water plant using cultivationbased and cultivation-independent methods. Water Res 44, 61246132.

Cashion, P., Holder-Franklin, M. A., McCully, J. \& Franklin, M. (1977). A rapid method for the base ratio determination of bacterial DNA. Anal Biochem 81, 461-466.

Chun, J., Lee, J. H., Jung, Y., Kim, M., Kim, S., Kim, B. K. \& Lim, Y. W. (2007). EzTaxon: a web-based tool for the identification of prokaryotes based on $16 \mathrm{~S}$ ribosomal RNA gene sequences. Int J Syst Evol Microbiol 57, 2259-2261.

Claus, M. (1992). A standardised Gram staining procedure. World J Microbiol Biotechnol 8, 451-452.

Collins, M. D., Pirouz, T., Goodfellow, M. \& Minnikin, D. E. (1977). Distribution of menaquinones in actinomycetes and corynebacteria. J Gen Microbiol 100, 221-230.

Collins, M. D., Routh, J., Saraswathy, A., Lawson, P. A., Schumann, P., Welinder-Olsson, C. \& Falsen, E. (2004). Arsenicicoccus bolidensis gen. nov., sp. nov., a novel actinomycete isolated from contaminated lake sediment. Int J Syst Evol Microbiol 54, 605-608.

Costerton, J. W., Cheng, K.-J., Geesey, G. G., Ladd, T. I. M., Nickel, J. C., Dasgupta, M. \& Marrie, T. J. (1987). Bacterial biofilms in nature and disease. Annu Rev Microbiol 41, 435-464.

Cowan, S. T. \& Steel, K. J. (1974). Manual of Identification of Medical Bacteria. London: Cambridge University Press.

Embley, T. M. \& Wait, R. (1994). Structural lipids of Eubacteria. In Chemical Methods in Prokaryotic Systematics, pp. 141-147. Edited by M. Goodfellow \& A. G. O’Donnell. New York: Wiley.

Euzéby, J. P. (1997). List of Bacterial Names with Standing in Nomenclature: a folder available on the Internet. Int J Syst Bacteriol 47, 590-592. 
Felsenstein, J. (1985). Confidence limits on phylogenies: an approach using the bootstrap. Evolution 39, 783-789.

Groth, I., Schumann, P., Rainey, F. A., Martin, K., Schuetze, B. \& Augsten, K. (1997). Demetria terragena gen. nov., sp. nov., a new genus of actinomycetes isolated from compost soil. Int J Syst Bacteriol 47, 1129-1133.

Groth, I., Schumann, P., Weiss, N., Schuetze, B., Augsten, K. \& Stackebrandt, E. (2001). Ornithinimicrobium humiphilum gen. nov., sp. nov., a novel soil actinomycete with L-ornithine in the peptidoglycan. Int J Syst Evol Microbiol 51, 81-87.

Hall, T. A. (1999). BioEdit: a user-friendly biological sequence alignment editor and analysis program for Windows 95/98/NT. Nucleic Acids Symp Ser 41, 95-98.

Hamada, M., lino, T., Iwami, T., Tamura, T., Harayama, S. \& Suzuki, K. (2009). Arsenicicoccus piscis sp. nov., a mesophilic Actinobacterium isolated from the intestinal tract of a fish. Actinomycetologica 23, 40-45.

Hasegawa, T., Takizawa, M. \& Tanida, S. (1983). A rapid analysis for chemical grouping of aerobic actinomycetes. J Gen Appl Microbiol 29, 319-322.

Hugh, R. \& Leifson, E. (1953). The taxonomic significance of fermentative versus oxidative metabolism of carbohydrates by various gram negative bacteria. J Bacteriol 66, 24-26.

Kimura, M. (1980). A simple method for estimating evolutionary rates of base substitutions through comparative studies of nucleotide sequences. J Mol Evol 16, 111-120.

Liu, X.-Y., Wang, B.-J., Jiang, C.-Y. \& Liu, S.-J. (2008). Ornithinimicrobium pekingense sp. nov., isolated from activated sludge. Int J Syst Evol Microbiol 58, 116-119.

Makk, J. \& Ács, É. (1996). Interaction between diatoms and bacteria in the biofilm of the Danube river. In Proceedings of the 31st International Conference of IAD, pp. 109-114. Vienna: IAD.

Mayilraj, S., Saha, P., Suresh, K. \& Saini, H. S. (2006). Ornithinimicrobium kibberense sp. nov., isolated from the Indian Himalayas. Int J Syst Evol Microbiol 56, 1657-1661.

Mesbah, M., Premachandran, U. \& Whitman, W. B. (1989). Precise measurement of the $\mathrm{G}+\mathrm{C}$ content of deoxyribonucleic acid by highperformance liquid chromatography. Int J Syst Bacteriol 39, 159-167.

Minnikin, D. E., Collins, M. D. \& Goodfellow, M. (1979). Fatty acid and polar lipid composition in the classification of Cellulomonas, Oerskovia and related taxa. J Appl Bacteriol 47, 87-95.

Murray, R. G. E., Doetsch, R. N. \& Robinow, F. (1994). Determinative and cytological light microscopy. In Methods for General and Molecular Bacteriology, pp. 21-41. Edited by P. Gerhardt, R. G. E. Murray, W. A. Wood \& N. R. Krieg. Washington, DC: American Society for Microbiology.

Patterson, M. K., Husted, G. R., Rutkowski, A. \& Mayette, D. C. (1991). Isolation, identification and microscopic properties of biofilms in high-purity water distribution systems. Ultrapure Water 8, 18-23.

Pearson, W. R. \& Lipman, D. J. (1988). Improved tools for biological sequence comparison. Proc Natl Acad Sci U S A 85, 2444-2448.

Poindexter, J. S. (1981). Oligotrophy: fast and famine existence. $A d v$ Microb Ecol 5, 63-89.

Rainey, F. A., Ward-Rainey, N., Kroppenstedt, R. M. \& Stackebrandt, E. (1996). The genus Nocardiopsis represents a phylogenetically coherent taxon and a distinct actinomycete lineage: proposal of Nocardiopsaceae fam. nov. Int J Syst Bacteriol 46, 1088-1092.
Reasoner, D. J. \& Geldreich, E. E. (1985). A new medium for the enumeration and subculture of bacteria from potable water. Appl Environ Microbiol 49, 1-7.

Saitou, N. \& Nei, M. (1987). The neighbor-joining method: a new method for reconstructing phylogenetic trees. Mol Biol Evol 4, 406425.

Schleifer, K. H. \& Kandler, O. (1972). Peptidoglycan types of bacterial cell walls and their taxonomic implications. Bacteriol Rev 36, 407-477.

Schumann, P., Kämpfer, P., Busse, H.-J., Evtushenko, L. I. \& Subcommittee on the Taxonomy of the Suborder Micrococcineae of the International Committee on Systematics of Prokaryotes (2009). Proposed minimal standards for describing new genera and species of the suborder Micrococcineae. Int J Syst Evol Microbiol 59, 1823-1849.

Smibert, R. M. \& Krieg, N. R. (1994). Phenotypic characterization. In Methods for General and Molecular Bacteriology, pp. 607-654. Edited by P. Gerhardt, R. G. E. Murray, W. A. Wood \& N. R. Krieg. Washington, DC: American Society for Microbiology.

Soini, S. M., Koskinen, K. T., Vilenius, M. J. \& Puhakka, J. A. (2002). Occurrence of bacteria in industrial fluid power systems. Clean Tech Env Policy 4, 26-31.

Stead, D. E., Sellwood, J. E., Wilson, J. \& Viney, I. (1992). Evaluation of a commercial microbial identification system based on fatty acid profiles for rapid, accurate identification of plant pathogenic bacteria. J Appl Bacteriol 72, 315-321.

Stieglmeier, M., Wirth, R., Kminek, G. \& Moissl-Eichinger, C. (2009). Cultivation of anaerobic and facultatively anaerobic bacteria from spacecraft-associated clean rooms. Appl Environ Microbiol 75, 34843491.

Tamaoka, J. \& Komagata, K. (1984). Determination of DNA base composition by reversed-phase high-performance liquid chromatography. FEMS Microbiol Lett 25, 125-128.

Tarrand, J. J. \& Gröschel, D. H. M. (1982). Rapid, modified oxidase test for oxidase-variable bacterial isolates. J Clin Microbiol 16, 772774 .

Thompson, J. D., Gibson, T. J., Plewniak, F., Jeanmougin, F. \& Higgins, D. G. (1997). The CLUSTAL_X windows interface: flexible strategies for multiple sequence alignment aided by quality analysis tools. Nucleic Acids Res 25, 4876-4882.

Traiwan, J., Park, M.-H. \& Kim, W. (2011). Serinicoccus chungangensis sp. nov., isolated from tidal flat sediment, and emended description of the genus Serinicoccus. Int J Syst Evol Microbiol 61, 1299-1303.

Xiao, J., Luo, Y., Xie, S. \& Xu, J. (2011). Serinicoccus profundi sp. nov., an actinomycete isolated from deep-sea sediment, and emended description of the genus Serinicoccus. Int J Syst Evol Microbiol 61, 1619.

Yamada, K. \& Komagata, K. (1972). Taxonomic studies on coryneform bacteria. IV. Morphological, cultural, biochemical, and physiological characteristics. J Gen Appl Microbiol 18, 399-416.

Yi, H., Schumann, P., Sohn, K. \& Chun, J. (2004). Serinicoccus marinus gen. nov., sp. nov., a novel actinomycete with L-ornithine and L-serine in the peptidoglycan. Int J Syst Evol Microbiol 54, 1585-1589.

Zhi, X.-Y., Li, W.-J. \& Stackebrandt, E. (2009). An update of the structure and 16S rRNA gene sequence-based definition of higher ranks of the class Actinobacteria, with the proposal of two new suborders and four new families and emended descriptions of the existing higher taxa. Int J Syst Evol Microbiol 59, 589-608. 